\title{
Kinetics and Solvent Effect on Hydrolysis of Ethyl Cinnamate in Water-Methanol Mixture
}

\author{
A.K. Singh \\ Department of Chemistry \\ Teerthanker Mahaveer University, Moradabad, India
}

\begin{abstract}
The solvent effect of aquo-dipolar protic solvent system was highlighted by studying the kinetics of base catalyzed solvolysis of ethyl cinnanmate in water-methanol media of various compositions having 20 to $70 \%$ (v/v)of ethanol at different five temp ranging from 20 to $40^{\circ} \mathrm{C}$. Fast decrease of specific rate constant with gradual addition of organic co solvent in the reaction media and also with increasing temperature of the reaction has been explained in light of solvation in initial and transition state to different extent. The change in Iso-composition Activation energy $\left(\mathbf{E}_{\mathrm{C}}\right)$ and Iso-dielectic Activation energy $\left(\mathbf{E}_{\mathrm{D}}\right)$ also explained the solvation and desolvation of initial and transition states to different extent The decrease in number of water molecule (1.59 to 1.42$)$ associated with the activated complex is found to be decrease in water-MEOH system and this tells about the fact that in presence of MEOH the mechanistic path of reaction is change from bio-molecular to uni-molecular. Increase in numerical value of free energy of activation $\left(\Delta G^{*}\right)$ simultaneous decrease in entropy of activation $\left(\Delta S^{*}\right)$ and enthalpy of activation $\left(\Delta \mathbf{H}^{*}\right)$, of reaction media reveals that ethanol acts as entropy inhibitor and Enthalpy stimulator.
\end{abstract}

Keywords - Solvent effect, ethyl cinnamate, Hydrolysis watermethanol mixture. Specific rate constant, Iso-composition and Isodielectric Activation energy, Activated complex.

\section{INTRODUCTION}

The effect of solvent on the rate and mechanism of alkali catalyzed hydrolysis of ester have received continued attention, but the explanation put forward is not satisfactory [1-3]. So, in order to explore the above idea, it was thought essential and useful to investigate about the fact that how ethyl cinnamate is useful as flavor and fragrance agent in cigarettes and cut tobacco. This compound is also used as food additive for human beings.

\section{EXPERIMENTAL}

Kinetic of alkali catalyzed solvolysis of ethyl cinnamate was studied by adding different concentrations of the protic organic co solvent(methanol) from 30 to $70 \%(\mathrm{v} / \mathrm{v})$ in reaction media at five different temperature i. e. $20^{\circ}, 25^{\circ}, 30^{\circ}, 35^{\circ} \& 40^{\circ}$ using volumetric method. All chemicals used were either of $\mathrm{BDH}$ or Merck grades. The strength of the solution was kept $0.1 \mathrm{M}$ with respect to $\mathrm{NaOH}$ and $0.05 \mathrm{M}$ with respect to ester.
The reaction rates were determined by titrating the sample at different time interval using phenolphthalein indicator. The specific rate constant value was calculated using second order reaction and tabulated in Table-I. Variation of specific rate constant with different mole $\%$ and different temperature are inserted in Table-2.

The value of slopes of Arrhenius plot of logk verses 1/T (Table-3) (Iso-composition activation energy $\left(\mathrm{E}_{\mathrm{c}}\right)$ and plots of logk verse D (Iso-dielectric activation energy) were evaluated and inserted in Table- $4 \& 5$ respectively. From the plots of Logk verses $\log \left[\mathrm{H}_{2} \mathrm{O}\right]$ Table- 6 , the value of slopes were evaluated and tabulated in Table-7. Thermodynamic Activation Parameter were also calculated and inserted in Table- 8

\section{RESULT AND DisCUSSION}

\subsection{Solvent Effect on Specific Rate}

In order to highlight the effect of the solvent on specific rate constant values(Tab-I) of the reaction, the logk values were plotted against the mole\% of organic co-solvent(their values from Table-2 as shown in fig-1) and were found to show decreasing trend. The plots show that with increase in the temperature of the reaction, the degree of depletion in the rate constant of the reaction becomes slower. However, the possible rate depleting factors in the rate can be enlisted as follows:

1. Decrease in bulk dielectric constant value of medium,

2. Decrease in the polarity of the reaction media by adding less polar methanol to it.

The above noted two depleting factors are quite in operation and are with good agreement with theory of Hughes and Ingold [4] that rate ought to decreases with decreasing dielectric constant of the reaction media. Such decrease in rate constant with increasing proportion of organic co-solvent like methanol have also reported by Elsemongy [5], and recently by Singh A K[6]. 
TABLE I. SPECIFIC RATE CONSTANT K X103(DM)3/MOLE/MINT]VALUES OF ALKALI CATALYZED HYDROLYSIS OF ETHYL-CINAMATE IN WATERMETHANOL

\begin{tabular}{|c|c|c|c|c|c|}
\hline \multirow{2}{*}{$\begin{array}{c}\text { Temp in } \\
{ }^{\circ} \mathrm{C}\end{array}$} & \multicolumn{5}{|c|}{ \% of Methanol } \\
\cline { 2 - 6 } & $30 \%$ & $40 \%$ & $50 \%$ & $60 \%$ & $70 \%$ \\
\hline $20^{\circ} \mathrm{C}$ & 8.31 & 6.60 & 5.43 & 4.46 & 3.75 \\
\hline $25^{\circ} \mathrm{C}$ & 2.56 & 9.74 & 7.85 & 6.59 & 5.37 \\
\hline $30^{\circ} \mathrm{C}$ & 18.15 & 13.96 & 11.09 & 9.12 & 7.58 \\
\hline $35^{\circ} \mathrm{C}$ & 26.24 & 19.90 & 15.48 & 12.88 & 10.47 \\
\hline $40^{\circ} \mathrm{C}$ & 27.15 & 28.18 & 21.57 & 17.78 & 14.45 \\
\hline
\end{tabular}

TABLE II. VARIATION OF 3 + LOGK VALUE AGAINST MOLE \%,( WATERMETHANOL) SYSTEM

\begin{tabular}{|c|c|c|c|c|c|c|}
\hline \multirow{2}{*}{$\begin{array}{c}\text { Temp } \\
\text { in }\end{array}{ }^{\mathrm{C}} \mathrm{C}$} & Mole\% & $20^{\circ} \mathrm{C}$ & $25^{\circ} \mathrm{C}$ & $30^{\circ} \mathrm{C}$ & $35^{\circ} \mathrm{C}$ & $40^{\circ} \mathrm{C}$ \\
\hline $30 \%$ & 16.03 & 0.920 & 1.099 & 1.259 & 1.419 & 1.570 \\
\hline $40 \%$ & 22.90 & 0.820 & 0.989 & 1.145 & 1.299 & 1.450 \\
\hline $50 \%$ & 30.82 & 0.735 & 0.895 & 1.045 & 1.190 & 1.330 \\
\hline $60 \%$ & 40.06 & 0.650 & 0.819 & 0.960 & 1.110 & 1.250 \\
\hline $70 \%$ & 50.97 & 0.565 & 0.730 & 0.880 & 1.020 & 1.160 \\
\hline
\end{tabular}

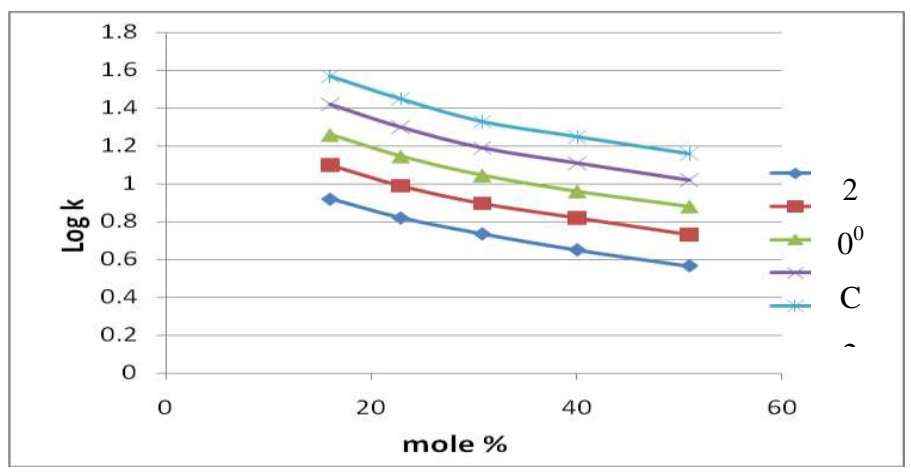

Figure 1. Variation of 3+Log $\mathrm{k}$ with mole\% (water-methanol system)

\subsection{Solvent effect on Iso-composition Activation Energy of the reaction}

From Tab- 4, (Fig-2) it is found that the values of Isocomposition Activation Energy goes on increasing [52.16 to $57.37 \mathrm{kj} / \mathrm{mole}$ ] with increasing concentration of $\mathrm{MEOH}$ from $30 \%$ to $70 \%(\mathrm{v} / \mathrm{v})$ in reaction media. The increasing trend in the $\mathrm{E}_{\exp }$ values can be explained by any of the following three situations.

1. Transition state is desolvated less than Initial state

2. Transition state is solvated more than the initial state

3. Transition state is solvated and initial state desolveted.

The transition state being large cat ion (ester $+\mathrm{H}+$ ) is available more for solvation by methanol molecule than the initial state, so third factor seem to operative in my case and is also supported by decrease in entropy of activation $\left(\square S^{*}\right)$. This conclusion is also supported recently by Singh $R$. T. et al.[7]
TABLE III. $\quad 3+$ LOGK VALUE AGAINST $10^{3} / \mathrm{T}$, WATER- METHANOL SYSTEM

\begin{tabular}{|c|c|c|c|c|c|c|}
\hline \multirow{2}{*}{$\begin{array}{l}\text { Temp } \\
\text { in }\end{array}{ }^{\circ} \mathrm{C}$} & $10^{3} / \mathrm{T}$ & $30 \%$ & $40 \%$ & $50 \%$ & $60 \%$ & $70 \%$ \\
\hline $20^{\circ} \mathrm{C}$ & 3.412 & 0.920 & 0.820 & 0.735 & 0.650 & 0.575 \\
\hline $25^{\circ} \mathrm{C}$ & 3.355 & 1.099 & 0.989 & 0.895 & 0.819 & 0.730 \\
\hline $30^{\circ} \mathrm{C}$ & 3.300 & 1.259 & 1.145 & 1.045 & 0.960 & 0.880 \\
\hline $35^{\circ} \mathrm{C}$ & 3.247 & 1.419 & 1.299 & 1.190 & 1.110 & 1.020 \\
\hline $40^{\circ} \mathrm{C}$ & 3.195 & 1.570 & 1.450 & 1.330 & 1.250 & 1.160 \\
\hline
\end{tabular}

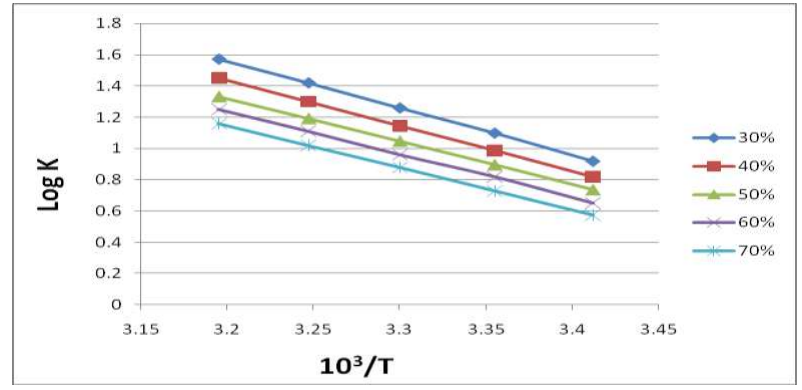

Figure 2. Variation of $3+\operatorname{Logk}$ against $10^{3} / \mathrm{T}$ (Water-methanol) system

TABLE IV. VALUES OF ISO-COMPOSITION ACTIVATION ENERGY (WATERMEOH MEDIA)

\begin{tabular}{|c|c|c|c|c|c|}
\hline $\begin{array}{c}\% \text { of } \\
\mathrm{MEOH}\end{array}$ & $30 \%$ & $40 \%$ & $50 \%$ & $60 \%$ & $70 \%$ \\
\hline $\begin{array}{c}\mathrm{E}_{\exp } \text { in } \\
\mathrm{KJ} / \mathrm{mole}\end{array}$ & 52.16 & 52.74 & 54.30 & 54.30 & 57.37 \\
\hline
\end{tabular}

\subsection{Solvent effect and Iso-Dielectric Activation Energy}

From the slope of Arrhenius plot of $\log \mathrm{k}_{\mathrm{D}}$ values against $1 / \mathrm{T}$, the value of iso-dielectric activation energy has been evaluated and recorded in Tab-5. From the table-5 and Fig-3, it is inferred that $\mathrm{E}_{\mathrm{D}}$ value goes on increasing from 55.45 to65.09 $\mathrm{kj} / \mathrm{mole}$ with increasing $\mathrm{D}$ values. This trend of variation is similar as $E_{c}$ values $(62.31$ to $64.88 \mathrm{KJ} / \mathrm{mole})$ (Tab5 ) with gradual addition of more solvent in reaction media. This interpretation was supported by past view of Wolford [8] recently supported by Singh R T. et al.[9]

TABLE V. VALUES OF ISO-DIELECTRIC ACTIVATION ENERGY (WATERMETHANOL)

\begin{tabular}{|c|c|c|c|c|c|}
\hline $\begin{array}{c}\text { Dielectric } \\
\text { constant(D) }\end{array}$ & $\mathrm{D}=45$ & $\mathrm{D}=50$ & $\mathrm{D}=55$ & $\mathrm{D}=60$ & $\mathrm{D}=65$ \\
\hline $\begin{array}{c}\mathrm{E}_{\exp } \text { in } \\
\mathrm{KJ} / \mathrm{mole}\end{array}$ & 55.45 & 57.95 & 62.19 & 62.76 & 65.09 \\
\hline
\end{tabular}

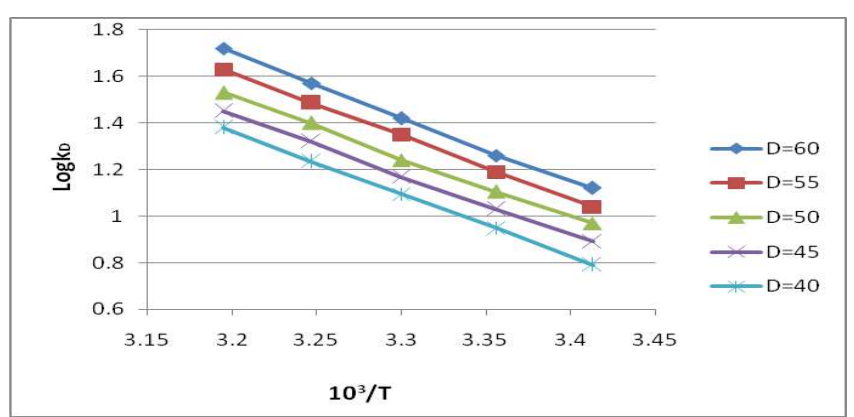

Figure 3. Variation of $3+\operatorname{Logk}$ against $10^{3} / \mathrm{T}$ (Water-methanol) system 


\subsection{EFFECT OF CONCENTRATION OF WATER MOLECULES [ $\left.\mathrm{H}_{2} \mathrm{O}\right]$, ASSOCIATED WITH THE ACTIVATED COMPLEX ON MECHANISTIC PATH OF THE REACTION}

The effect of water concentration $\left[\mathrm{H}_{2} \mathrm{O}\right]$ of the waterethanol mixture, on rate and mechanism of alkali catalysed hydrolysis of ethyl cinnamate has been studies. For this, the number of water molecule associated with activated complex was determined by plotting $\log k$ against $\log \left[\mathrm{H}_{2} \mathrm{O}\right]$, According to Robertson[10] relation

\section{$\log \mathrm{k}=\log \mathrm{k}_{0}+\mathrm{nlog}\left[\mathrm{H}_{2} \mathrm{O}\right]$}

Here $\mathrm{n}$ is the solvation number and decide the criteria about the mechanism of reaction.

From noted value of slope mention in Table-7, it may be seen that with rise of temperature from 20 to $70^{\circ} \mathrm{C}$, the value of slope (number of water molecule associated with activated complex) goes on increasing from (2.08 to 2.56). This observation may be attributed to the fact that with addition of ETOH in reaction media, the equilibrium of water component reaction media shifted from its dense form to its bulky form with rise of temperature.

$\left[\mathrm{H}_{2} \mathrm{O}\right]_{\mathrm{d}} \square\left[\mathrm{H}_{2} \mathrm{O}\right]_{\mathrm{b}}$

Finally, it is inferred that with rise of temperature, the number of water molecule associated with activated complex increases as the proportion of bulky form of water molecule increase with increase in MEOH content in the water-ethanol mixture and it explain that when $\mathrm{MEOH}$ is added to water, the mechanistic path of reaction is changed from biomolecular to unimolecular in similar way as observed by parker and Tomilinson[11] and recently by Singh A K [12]

TABLE VI. VARIATION OF 3+ LOG K WITH LOG [ H2O] (WATER METHANOL) AT DIFFERENT TEMPERATURE

\begin{tabular}{|c|c|c|c|c|c|c|c|}
\hline \multirow{2}{*}{$\begin{array}{l}\% \text { of } \\
\text { Acet } \\
\text { one }\end{array}$} & \multirow{2}{*}{$\begin{array}{l}\% \text { of } \\
\mathrm{H}_{2} \mathrm{O}\end{array}$} & \multirow{2}{*}{$\begin{array}{l}\mathrm{Log} \\
{\left[\mathrm{H}_{2} \mathrm{O}\right]}\end{array}$} & \multicolumn{5}{|c|}{$3+\log k$} \\
\hline & & & $20^{\circ} \mathrm{C}$ & $25^{\circ} \mathrm{c}$ & $30^{\circ} \mathrm{c}$ & $35^{\circ} \mathrm{c}$ & $40^{\circ} \mathrm{c}$ \\
\hline $30 \%$ & $70 \%$ & 1.5690 & 0.890 & 1.075 & 1.210 & 1.70 & 1.570 \\
\hline $40 \%$ & $60 \%$ & 1.5229 & 0.820 & 0.989 & 1.145 & 1.290 & 1.500 \\
\hline $50 \%$ & $50 \%$ & 1.4437 & 0.735 & 0.895 & 1.045 & 1.190 & 1.390 \\
\hline $60 \%$ & $40 \%$ & 1.3468 & 0.650 & 0.819 & 0.965 & 1.090 & 1.280 \\
\hline $70 \%$ & $30 \%$ & 1.2218 & 0.565 & 0.730 & 0.880 & 0.980 & 1.160 \\
\hline
\end{tabular}

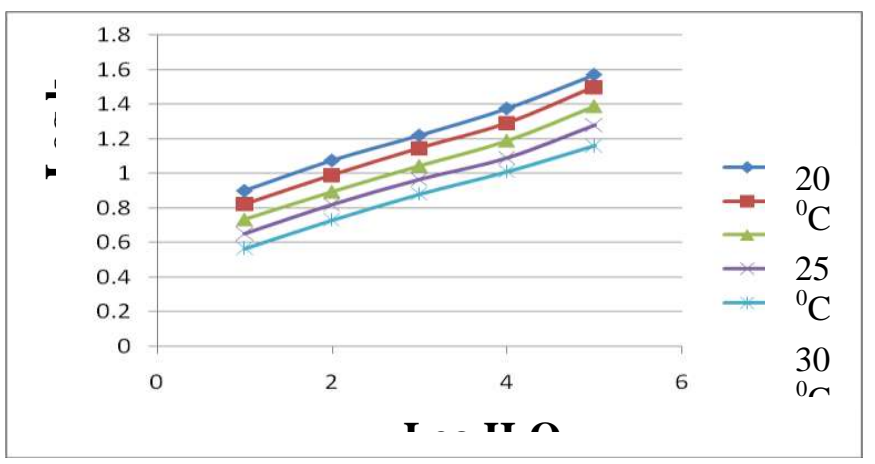

Figure 4. Variation of $3+\operatorname{Logk}$ against $10^{3} / \mathrm{T}$ (Water-methanol) system
TABLE VII. CALCUlated VAlues of SLOPES (Plot OF LOG K VERSES LOG $\left[\mathrm{H}_{2} \mathrm{O}\right]$ ) OF WATER-METHANOL MEDIA

\begin{tabular}{|c|c|c|c|c|c|}
\hline Temp ${ }^{\circ} \mathrm{C}$ & $20^{\circ} \mathrm{c}$ & $25^{\circ} \mathrm{c}$ & $30^{\circ} \mathrm{c}$ & $35^{\circ} \mathrm{c}$ & $40^{\circ} \mathrm{c}$ \\
\hline Slope & 2.08 & 2.16 & 2.21 & 2.29 & 2.56 \\
& & & & & \\
\hline
\end{tabular}

TABLE VIII. CONSOLIDATED VALUES OF THERMODYNAMICS ACTIVATION PARAMETERS $\left(\Delta \mathrm{H}^{*}\right.$ AND $\Delta \mathrm{G}^{*}$ IN KJ/MOLE, $\Delta \mathrm{S}^{*}$ IN J/K/MOLE $)$ OF THE REACTION IN WATER-METHANOL MEDIA

\begin{tabular}{|c|c|c|c|c|c|c|c|c|c|c|c|c|}
\hline$\%$ & Mo & $\Delta \mathrm{H}$ & \multicolumn{2}{|c|}{$20^{\circ} \mathrm{C}$} & \multicolumn{2}{|c|}{$25^{0} \mathrm{C}$} & \multicolumn{2}{|c|}{$30^{\circ} \mathrm{C}$} & \multicolumn{2}{|c|}{$35^{0} \mathrm{C}$} & \multicolumn{2}{|c|}{$40^{\circ} \mathrm{C}$} \\
\hline $\begin{array}{c}\text { M } \\
\text { EO } \\
\text { H }\end{array}$ & $\%$ & $\begin{array}{c}\mathrm{Kj} / \\
\mathrm{Mo} \\
\mathrm{le}\end{array}$ & $\Delta \mathrm{G}$ & $\begin{array}{c}- \\
\Delta \mathrm{S}\end{array}$ & $\Delta \mathrm{G}$ & $\begin{array}{c}- \\
\Delta \mathrm{S}\end{array}$ & $\Delta \mathrm{G}$ & $\overline{\Delta S}$ & $\Delta \mathrm{G}$ & $\overline{\Delta S}$ & $\Delta_{*} \mathrm{G}_{\mathrm{G}}$ & $\overline{-}$ \\
\hline 30 & 16. & 53. & 93. & 13 & 94. & 1. & 94. & 1 & 95. & 13 & 96. & 13 \\
\hline$\%$ & 03 & 31 & 64 & $\begin{array}{c}7.6 \\
4\end{array}$ & 27 & $\begin{array}{c}7.4 \\
4\end{array}$ & 98 & $\begin{array}{c}7.5 \\
2\end{array}$ & 60 & $\begin{array}{c}7.3 \\
0\end{array}$ & 31 & $\begin{array}{c}7.3 \\
8\end{array}$ \\
\hline 40 & 22 & 52 & 94. & 14 & 94. & 13 & 95 & 14 & 96. & 14 & 97. & 14 \\
\hline$\%$ & 90 & 95 & 20 & $\begin{array}{l}0.7 \\
8\end{array}$ & 91 & $\begin{array}{c}8.4 \\
2\end{array}$ & 65 & $\begin{array}{c}0.8 \\
9\end{array}$ & 31 & $\begin{array}{c}0.7 \\
7\end{array}$ & 03 & $\begin{array}{c}0.8 \\
3\end{array}$ \\
\hline 50 & 30. & 52 & 94. & 14 & 95. & 14 & 96. & 14 & 96. & 14 & 97. & 14 \\
\hline$\%$ & 82 & 87 & 68 & 2.6 & 44 & $\begin{array}{c}0.3 \\
0\end{array}$ & 23 & $\begin{array}{l}3.1 \\
0\end{array}$ & 96 & $\begin{array}{c}3.1 \\
4\end{array}$ & 75 & $\begin{array}{c}3.3 \\
8\end{array}$ \\
\hline 60 & 40. & 51. & 95. & 14 & 95. & 14 & 96. & 14 & 97. & 14 & 98. & 15 \\
\hline$\%$ & 06 & 28 & 16 & $\begin{array}{c}9.7 \\
6 \\
\end{array}$ & 88 & $\begin{array}{c}7.2 \\
4 \\
\end{array}$ & 72 & $\begin{array}{c}9.9 \\
6 \\
\end{array}$ & 43 & $\begin{array}{c}9.8 \\
3 \\
\end{array}$ & 23 & $\begin{array}{c}0.0 \\
0\end{array}$ \\
\hline $\begin{array}{l}70 \\
\%\end{array}$ & $\begin{array}{l}50 . \\
97\end{array}$ & $\begin{array}{l}50 . \\
51\end{array}$ & $\begin{array}{r}95 . \\
64\end{array}$ & $\begin{array}{l}15 \\
4.0 \\
2\end{array}$ & $\begin{array}{c}96 . \\
39\end{array}$ & $\begin{array}{c}15 \\
1.4 \\
4\end{array}$ & $\begin{array}{r}97 . \\
19\end{array}$ & $\begin{array}{c}15 \\
4.0 \\
5\end{array}$ & $\begin{array}{l}97 . \\
96\end{array}$ & $\begin{array}{c}15 \\
2.5 \\
6\end{array}$ & $\begin{array}{l}98 . \\
77\end{array}$ & $\begin{array}{l}15 \\
4.1 \\
8\end{array}$ \\
\hline
\end{tabular}

\section{CONCLUSION}

In hydrolysis of Ethyl cinnamate, the decreasing trend of specific rate constant at all temp with increasing mole\% of cosolvent which show that the decrease is either due to bulk dielectric constant value of medium or decrease in the polarity of the reaction media by adding less polar methanol to it. The values of Iso-composition Activation Energy goes on increasing $[52.16$ to $57.37 \mathrm{kj} / \mathrm{mole}]$ with increasing concentration of $\mathrm{MEOH}$ from $30 \%$ to $70 \%(\mathrm{v} / \mathrm{v})$ in reaction media indicate Transition state is solvated and initial state desolveted.Increase in the value of and $\Delta \mathrm{G}^{*}$ with simultaneous increase in $\Delta \mathrm{H}^{*} \& \Delta \mathrm{S}^{*}$ for the hydrolysis ethyl cinanimate in water- Methanol is enthalpy dominating and Enthalpy control. The linear plots obtained by plotting logk as function of D represent the different electrostatic interaction for the iondipole as well as dipole - dipole reaction. Solvating power of $\mathrm{MEOH}$ change the mechanism of the reaction from biomolecular to unimolecular due to increase in number of water molecule associated with activated complex (2.08to 2.56).

\section{REFERENCES}

[1] A.K Singh, "A Kinetics Study of Solvent Effect on Thermodynamics Activation Parameter on alkali catalyzed Solvolysis of Methyl Saliccylate in water-DMF Media". Inter. Jounrnal of Adv. Research and Innovation .Vol-3, Issue -3 2015. PP. 547-549

[2] Magda F. Fathalla, "Kinetics of Reaction of 2-Chloro-quinoxaline with Hydroxide Ion in CAN-H2 O and DMSO-H2O Binary Solvent Mixture", J. Solution Chem., 2011, 40, 1258-70,

[3] Singh. A.K," Solvent Effect On Solvolysis Rate in Alkalaline Hydrolysis of Ethyl Acetate in water-Methanol and water-ethanol mixed solvent 
system”. Inter. J.for Res. In Applied Science \& Engg. Tech. (IJRASET), Vol.-4, Issue-IX., Sep2016, pp 505-509

[4] Hughes E.D. and Ingold C.K, " Mechanism of substitution at saturated carbon atom part IV, A discussion of constitution and solvent effect on mechanism, kinetics, velocity, and orientation of substitution". $\mathrm{j}$ chem. Soc 1935, 244- 255

[5] M.M. ElsemongyAbu, Elamayn, M S and Moussa: Z. phys. chem. 84, $1973,294$.

[6] Singh A.K. "The influence of solvent on the solvolysis of Ethyl cinnamate in water-Acetone mixtures."International Journal of Engineering and Applied Computer Science [IJEACS] 2017. Pp79-82

[7] Singh R T et al. "kinetic studies on the dielectric effect of water-ter. butanol media on solvolysis of caproate ester".Napier Indian Advance Research Journal of Science[NIARJSc]. Vol-12, Sep 2012. Pp77-81

[8] Wolford, R K.: "Kinetics of the Acid-Catalyzed Hydrolysis of Acetal in Dimethyl Sulfoxide- Water Solvents at 15, 25, and 35" J. Phys. Chem., 1964, 68 (11), pp 3392-3398J. Phys.chem. 68, 3392, 1964

[9] Singh R. T. et al. "Studies on the solvent effect of aquo-alcohal solvent system on the solvolysis of aliphatic methanoate." Napier Indian Advance Research Journal of Science [NIARJSc]. Vol-12, Sep 2012. Pp 89-100.

[10] R.E. Robertson, "A survey of thermodynamic parameter for solvolysis in water", Prog. Phy.Org. chem. 4, 1967 pp213

[11] Parker, K J. and Tommillionson, D J. Trans. Faraday Soc. 67, 1302, 1971

[12] Singh A K. "The Influence of Solvent on the Solvolysis of Ethyl Cinnamate in Water Acetone Mixed Solvent System". International Journal of Engineering and Applied Computer Science (IJEACS) Volume: 02, Issue: 02, February 2017.

\section{AUTHOR PROFILE}

Dr. A. K. Singh is working as Asst. Professor of Chemistry in College of Engineering of Teethankar Mahaveer University, Moradabad, India since 2010. He holds Master of Science in Physical Chemistry, awarded in 1989, from Magadh University, Gaya followed by Doctor of Philosophy (Ph.D.) in Kinetic Solvent Effect, awarded in 2009 from VKS University Ara, India. He has studied different salvation capacity of different reaction media (e.g. Water-DMSO, Water-

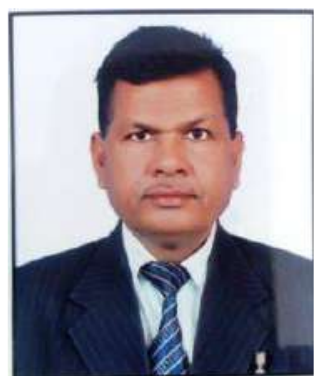

DMF,Water-Aceton. Water-Methanol etc) on the Specific Rate Constant value of the Reaction, the Iso- Composition, Iso- Dielectric Activation Energy, the Number of Water and Solvent Molecules Associated the Activated complex of the Reaction in order to decide the Nature of Mechanistic path of the Reaction, Thermodynamic Activation Parameter of the Reaction, the value of Iso Kinetic Temp on the Reaction in order to Explore the Idea of SolventSolute Interaction in More Media. He has published seventeen research articles in his credits.

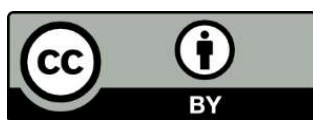

(C) 2017 by the author(s); licensee Empirical Research Press Ltd. United Kingdom. This is an open access article distributed under the terms and conditions of the Creative Commons by Attribution (CC-BY) license. (http://creativecommons.org/licenses/by/4.0/). 